\title{
Cultural, Interpersonal Relationships and Communication Challenges as Perceived by Nigerian Post-graduate Students in a Public Academic Institution in Malaysia
}

\author{
Azirah Hashim \\ Asia-Europe Institute, University of Malaya, Kuala Lumpur, Malaysia \\ Seyed Yasin Yazdi-Amirkhiz \\ Department of Foreign Languages, Tehran University of Medical Sciences, Tehran, Iran \\ Mohammed Nuruddeen Suleiman \\ Asia-Europe Institute, University of Malaya, Kuala Lumpur, Malaysia
}

\begin{abstract}
This study explored Nigerian post-graduate students' perceptions of intercultural communication challenges faced in the wider socio-cultural context of society as well as in the setting of a higher education institution in Malaysia. Core findings of two focus group interviews with fourteen Nigerian students are reported. Interviews were audio-recorded, transcribed and coded. Inductive qualitative analysis was used to determine categories and themes which emerged in the focus groups' data. The main highlights discovered were the issues of local media's indiscriminate generalizations and biased coverage of activities of Nigerians. The informants also referred to Malaysians' natural proclivity for silence and their poor responsiveness in communicative interactions, the language barrier as well as religion-induced discriminations as factors contributing to the inefficacy of intercultural communication. The findings are discussed with reference to the macro-cultural patterns of world cultures as well as the culture-specific qualities of the Malaysian society.
\end{abstract}

Keywords: Intercultural communication challenges; Malaysia; Nigerians

\section{INTRODUCTION}

Over the past two decades Malaysia has recorded an unprecedented flow of people into the country from across diverse cultures around the globe, and one of the major attractors has proved to be the country's higher educational institutions owing to its "favorable environment and cost competitiveness" (Thuraisingam \& Singh 2010, p. 91). About 71,000 international students were enrolled in the universities across Malaysia in 2011 (Ministery of Education, 2012), and the government is targeting around 250,000 foreign students in the country by 2025 (Ministry of Education, 2015). The official figures issued by Malaysia's higher education Ministry (Therin, 2012) also indicate a steady growth in the number of African students at the academic institutions of the country, with Nigerians accounting for the majority of the existing African students' population.

It is a truism that the influx of foreign students into a country naturally ensues the escalation of intercultural contact between them and the host community. This has led to frequent reports by the local and foreign media (e.g., Malaymailonline, 2013; Freemalaysiatoday, 2018; Pulse.ng, 2018; South China Morning Post, 2018; The Sun Daily, 2020; Africa Check, 2020) about the unfavorable stance of Malaysian community against Nigerian sojourners in Malaysia. For example, as reported by South China Morning Post (2018), residents at a condominium complex in Cheras, a municipality outside Kuala Lumpur, made headlines when they put up a banner encouraging landlords to "say no to African people". The bright red banner also bore the image of a dark-skinned man with a large yellow $\mathrm{X}$ across his face. A reference can also be made to the comments by official authorities as exemplified in the advice by Senator Datuk Paul Kong Sing Chu: "The best is to totally avoid them [African students]" (Lai, 2011). More recently, The Sun Daily (16 APR 2020) is showing a photo of a banner outside an apartment in Kuala Lumpur in different languages. The English text reads: "DO NOT RENT TO AFRICAN/NEGRO" and " $0 \%$ AFRICAN/NEGRO TENANT". A red circle around the words "AFRICAN NEGRO" has a diagonal line through it in the common symbol for "not allowed".

The present study is, therefore, an aim to scrutinize the interpersonal relationships and intercultural communication challenges from the perspective of Nigerian post-graduate students in an academic institution in Malaysia. Bearing such an objective in mind, the following question was posed to guide the study:

How do Nigerian post-graduate students in a public university in Malaysia perceive their interpersonal relationships and intercultural communication challenges with Malaysians? 


\section{Yinternational Research Journal}

p-ISSN 2202-2821 e-ISSN 1839-6518 (Australian ISSN Agency)

\section{II.LITERATURE REVIEW}

There is extensive literature on the study of intercultural contacts and interactions between international students and the host communities across the globe (e.g. Porter \& Samover, 1997; Tubbs \& Moss, 2000; Williams \& Johnson, 2011; Ruble $\&$ Zhang, 2013). A large number of the existing studies in intercultural communication have explored the experiences of international students to adapt to new cultural settings and most of the studies converge in the finding that the incidence of intercultural interaction between the international students and the host nationals is normally low. This is by no means surprising in view of the fact that intercultural communication and contact are inherently prone to contentions in that the natural differences between cultures often give rise to communication problems (e.g., Irwin 1996; Porter \& Samover, 1997) or misunderstanding (Tubbs \& Moss, 2000). A study by Williams and Johnson (2011) found that even in the United States where people come from diverse cultures and backgrounds, international students still face the challenges associated with adaptation. The study suggested that international students in the United States are finding it increasingly hard to make and keep local friends. Hence they prefer to have friends from their own ethnic group or from among other international students in the country. In another study conducted by Brown (2009) in Britain, it was revealed that international students in Britain considered the local people unapproachable and unfriendly thus making it hard for them to establish any sort of relationship.

Antonio (2004) explored the effect of the variables of ethnicity and race on the decisions of the students of an American university to make friends within the campus and found that race and ethnicity were not absolute determinants for developing friendship. Poyrazli and Lopez (2007) investigated the relationship between the ethno-racial background and the residence duration of the international students in the United States with their degree of perceived discrimination. Their study suggested that non-European international students perceived themselves to be more discriminated in the university and that the longer their duration of stay in the country was, the stronger their sense of being discriminated against was. Similar findings were reported by Poyrazli et al. (2010) who found a relationship between race and ethnicity of the foreign students in America with their level of perceived discrimination. Similar findings are found in Smith and Khawaja's (2011) study, indicating that along with the sense of discrimination, the language barrier and differences in cultural norms hampered the international students' acculturation.
Vol. 12 No. 012022

828012012022178 (C) Author(s)

A number of scholars have approached the issues related to international students through investigation of the host community's views and/or perceptions of international students. For example, the study of Ruble and Zhang (2013) gauged the stereotypical view of American students towards their Chinese counterparts studying in the country. The study identified two positive traits (i.e., hardworking and friendly) and three negative traits (i.e., speaking bad English, not very sociable, annoying) which were stereotypically ascribed to the Chinese students by their American counterparts. Marlina (2009), who explored the perception that Asian students were stereotyped as unreceptive in the western world, found that besides this perceived Asian cultural norm, the students' passivity was also attributable to their view of the unmotivational classroom behaviors of the tutors and the way the teachers moderated the sessions. Consistent with the findings of the previous studies, Hanassab (2006) and Lee and Rice (2007) also found out that international students were perceived to be racially discriminated and were generally stereotyped, particularly those from Asia and Africa (Sam, 2001). As for the factors causing or contributing to the sense of discrimination by the foreign students, Hessler's (2006) study which was on African students in Russia found that cultural misunderstanding was one of the major sources of conflict between the host and African students. This was further compounded by interracial relationships between African male students and their female hosts which created prejudicial feelings in the local males. Numerous cases are cited by the study to illustrate physical and verbal abuses suffered by African students in their host country, contributing to nurturing the perception of racial profiling and discrimination in the heart of the Africans.

Intercultural communication between foreign students and the host community has also been investigated on the basis of the macro-cultural dichotomy of world cultures (i.e., collectivist/ individualist). Individualism represents a social framework in which individuals view themselves as independent of groups or collectives. The individual's interests, needs, rights and goals have preference over those of a group. Collectivism, in contrast, indicates a system in which individuals are encouraged to perceive themselves as an inseparable part of the in-group and priority is given to the views and needs of the group rather than those of an of independent individual (Hofstede, 1986; Triandis, 1995). Min-Sun Kim (2002, as cited in Kumaravadivelu 2008, p.15) provides a sociological account of the West and the East (East Asian Cultures) indicating differences between the two: 


\section{The West:}

European-American notions of personality are afforded and maintained by a great many cultural meanings, including the idea that difference among people is obvious and good; the belief that a person can be separated from society or the social situation; and the assumption that social behavior is rooted in, and determined by, one's underlying traits.

\section{The East:}

The self is defined predominantly in terms of relationships and group membership. In this alternative view, the self is inherently social-an integral part of the collective. The key feature of interdependence is not distinctiveness or uniqueness, but a heightened awareness of the other and of the nature of one's relation to the other.

Jang and Kim (2010) in their investigation of the acculturation of exchange students from collectivist and individualist countries in two distinctive societies concluded that the collectivist students adapted and learnt more easily irrespective of their personality whereas the students with individualistic orientations needed to be more open-minded.

As far as the acculturation and life experiences of international students in Malaysia are concerned, a few studies are recorded in the literature. Thuraisingam and Singh (2010) studied the intercultural adaptation of 21 international students from seven countries (3 students from each of the countries: Maldives, Mongolia, Nigeria, Indonesia, Korea and India) who were studying in a private higher education institute in Malaysia. The themes that were generated from the qualitative data from the participants such as prejudice and cultural shock suggested the students had encountered challenges in the acculturation process. The study importantly pointed out that the Korean students felt less discriminated while the Nigerian students felt highly unaccepted and unwelcomed by the Malaysians. Yusoff and Chelliah (2010) studied the socio cultural and psychological adjustment process of international students in Malaysian universities. The study concluded that the ability of international students to have "conscientiousness and agreeableness" (p. 277) with the new culture and environment will ensure their quick adaption. However, the study of Pandian (2008) which focused on multicultural experiences of Middle Eastern students at University Science Malaysia indicated that the greater percentage of students from the Middle East adapted easily and were not discriminated by the local Malaysians. Some participants expressed some discontent with the attitudes of local students. Nonetheless, the study also suggested that some Middle Eastern students shied away from making local friends due to communication problems that existed.
Overall, a review of the pertinent literature reveals that an overwhelming majority of studies on international students have been conducted in developed countries in that the West has traditionally been the prime destination of educational sojourners of developing and less developed countries; however, with the recent attenuation of the West's monopoly over the enterprise of global tertiary education, and the emergence of new 'players' such as Malaysia who are targeting to be the hub of education in South- east Asia (MOHE, 2011), conducting studies of this kind seems warranted in order to show the dynamics of the intercultural communication between the host and the guest community.

\section{METHODOLOGY}

\section{Data collection and analysis}

This study was conducted in Malaysia. The setting was a wellknown public university in Kuala Lumpur with a sizeable population of international students. Before starting the study, we approached a number of Nigerian students majoring in a variety of disciplines at the same university and fourteen postgraduate students agreed to participate in the study. The age of the participants varied between 24 and 39. Given the ethno-religious and demographic composition of Nigeria, where Muslims and Christians account for almost an equal proportions of the total population, an attempt was made to recruit an evenly distributed number of interviewees based on their religious affiliation and gender; however, the intended even distribution did not materialize. The participants were 9 male Muslims, 3 female Muslims and only 2 male Christians, who were assigned into two focus groups (i.e., seven in each focus group).

The researchers used some time at the outset of the interview sessions to establish rapport with the participants. They were then briefed on the objectives of the study again, and were assured of the confidentiality of their identities as well as the content of the discussion during the sessions. The point to be made here is that the session moderators were deliberately chosen to be non-Malaysian in view of the fact that "the interview is constituted by complex relations of power, which can be differentially realized in many ways: who chooses what-- and what not - to discuss; who asks what questions, when and how" (Talmy 2010, p. 137). The "race" and "institutional status" of the interviewers can also have implications for the interviews and the findings (p. 137). The non-Malaysian status of the session moderators might have given the interviewees the reassuring impression of "we are also like you guests in this country, and are now talking about our common host'. This sense might have plausibly enhanced the validity of the elicited data from the interviewees. 


\section{Yinternational Resoarch Journa}

p-ISSN 2202-2821 e-ISSN 1839-6518 (Australian ISSN Agency)

There was a set of prepared questions for the focus groups, but the discussion was allowed to flow in relation to their life experiences in Malaysia, their overall attitudes towards the local people's typical patterns of everyday communicative behaviors, the challenges of intercultural communication norms, etc. Each session lasted for around two hours. The sessions were entirely audio-recorded and transcribed in full by the interviewers themselves. The transcribed data were subsequently coded through the global qualitative approach: the categories and themes emerged through the reiterative process of reading and re-reading the data. The common patterns and recurring themes which emerged from the analysis of the interviewees' remarks during the two focus group interviews are reported.

\section{FINDINGS AND DISCUSSION}

The analysis of the interviewees' verbal interactions revealed their overall perceptions of intercultural communication challenges faced in the wider socio-cultural context of society as well as in the setting of their alma mater in Malaysia, which were reflected in the content and language of the interactions.

As one of the main themes emerging from the interactions of the informants was the worsening of Malaysians' perceptions towards Nigerians over the past years. Almost all of the informants agreed that Malaysians were normally welcoming towards foreigners, yet asserted that they had observed a steady and conspicuous negative change of attitudes towards Nigerians in recent years. A few of the sample comments provided by the participants are as follows.

\section{Informant 3:}

I have been in this country for about 7 years... but the major issue we have in this country is the negative perception created about Nigerians over time due to the crimes of some [Nigerians].

\section{Informant 10:}

...if you ask me to describe Malaysians, I would say they are amongst the most humble and somewhat intelligent people. However, the perception they have developed on Nigerians is the only thing making them not receptive towards us.

\section{Informant 5:}

The main reason for the reputation of Nigerians in Malaysia is the issue of crimes perpetrated by a few individuals over the years, and this is the major reason why there is a wide gap in terms of communication and friendship between Nigerians and Malaysians.

As it is shown above from the informants' perspective, the negative perceptions of Malaysians towards Nigerians seemed to have been developed in the course of time. To some of the informants, the attitudes and behaviors exhibited by some Malaysians vis-à-vis Nigerians bordered on Nigerian phobia. There was a specific reference to a number of 'tenancy ban' cases in some condominiums in Kuala Lumpur. The owners were asked not to rent out the units to Africans anymore, to cancel the tenancy agreements and also to vacate their African tenants from the units within three months. In support of the existence of such a so-called 'Nigerian-phobic' sentiment among the Malaysians, interviewees shared their personal anecdotes as follows.

\section{Informant 9:}

...Some of them even get out of the elevator once [they] find themselves alone with a Nigerian in an elevator or even will not get on the elevator when they see you inside...

\section{Informant 4:}

...Some of them hold their noses when standing beside or passing by us..

\section{Informant 11:}

When I arrived in Malaysia in the first time, I faced a lot of difficulties... nobody even wants to talk to you, and it is like they are running away from you...during my Master's days, some Malaysians do approach me and ask where I am from, and immediately I tell them from Nigeria, they abandon me.

\section{Informant 3:}

...if you get into a train and sit next to a Malaysian, he or she may decide to get up, and it is because you are black...

A few also alluded to certain experiences on campus, of which two are presented below:

\section{Informant 7:}

...Malaysian colleagues avoid us even for academic conversation...I have noticed they are calm, very gentle, but not friendly..

\section{Informant 2:}

Sometimes the Malaysians are underrating us; some of them think that we lack all the good things in our country that is why we are in Malaysia studying. For instance, during a lecture one of our lecturers asked me if we still have our classes under the tree in my country... she was just trying to embarrass me in the class... I was off balance.

The feedback provided by the Nigerian informants clearly showed that they felt they were stereotyped by Malaysians, arguing that the defective generalizations from the wrongdoing of a small sample of Africans involved in criminal 


\section{Yinternational Research Journal}

p-ISSN 2202-2821 e-ISSN 1839-6518 (Australian ISSN Agency)

activities to the whole population of black people rendered achieving an effective intercultural communication elusive and increasingly difficult. It was essentially perceived that as a consequence of stereotypifi-cation and indiscriminate generalizations, not only Nigerian students but also every black-skinned person was by default considered a 'potential criminal'. Crawley et al. (2013) have likewise blamed similar defective generalizations for many African students not having local friends. A direct association has been postulated between the physical distinctiveness and the vulnerability of the sojourners. For instance, in Brown's (2003) study the whiteness of Polish economic migrants was found to be a factor protecting them from attack in the U.K., and Brown (2009) found that the physically distinguishing appearance increased the vulnerability of Asian students on the university campus.

Another highly frequent theme in the data was concerned with the students' criticism against the performance of local media in Malaysia. There was a consensus that the local media was projecting a biased picture of the issues pertaining to Nigerians, arguing that whereas the negative side was getting inflated, the positive side was hardly given any coverage. A few of the informants' comments are presented below.

\section{Informant 14:}

Well! we have Nigerian students that are criminals... but I believe it is a stereotype that has been built overtime... so many negative things have been said about us in Malaysia...So I believe some of the Malaysians grew up with that stereotype in their minds... and the media contributes to this perception.

\section{Informant 1:}

In fact there are times when some things happen in your presence, and by the time you see it in the media, the story is totally portrayed differently in a negative way, and over one million people on the street will read or hear it.

\section{Informant 6:}

I have never heard in the media that a Nigerian graduated with a first class Degree in Malaysia... but when it is an issue pertaining [to] drugs, they will even show it in the National news...

Informant 10 postulated the existence of a planned conspiracy to tarnish the image of the Nigerians in Malaysia, and accused some people from the local media of following an "agenda". According to him, after the incidence of a crime in one of the neighborhoods of Kuala Lumpur, a reporter and a cameraman from one of the local news outlets had approached a foreign student on the scene of the crime and had asked him, in return
Vol. 12 No. 012022 828012012022178 (C) Author(s)

for money, to blame the offence on Nigerians. The sense of suspicion and mistrust on the part of the 'guest' can lead to extreme miscommunication scenarios. Gudykunst (1998) posits that miscommunication is most likely to occur between the members of a suspicious minority and a prejudiced majority. A reference can also be made to the comments by official authorities as exemplified in the advice by Senator Datuk Paul Kong Sing Chu: "The best is to totally avoid them [African students]" (Lai, 2011). However, there should be little doubt that shunning the African students would not be a viable option because it can increase the distance and isolation of African students, which can in turn lead to further resentment and misunderstanding. According to Barnett and Lee (2002), unless "the cultural information between two groups of people with significantly different cultures" ( $p$. 275), is exchanged, achieving intercultural communication and consequently building up mutual trust and respect would be impossible.

Two other themes recurring in the data were concerned with Malaysians' proclivity for silence and their poor responsiveness in communicative interactions. Having been asked about the typical communicative behaviors and interactional norms of the Malaysians, the informants described them as normally being reticent, and having a lower tendency to initiate conversations. It was also complained that even at times when they had tried to approach and initiate a talk with the locals and even their workplace colleagues, their 'action' had not been warmly reciprocated. A few sample remarks of the informants concerning their local interlocutors' reticence and imbalanced vocal reciprocations are presented as follows:

\section{Informant 3:}

I have been in this country for about 7 years, I have interacted with them a lot, but they hardly say hello to you. But generally speaking, a typical Malaysian is shy...I believe this is an issue of cultural differences...

\section{Informant 7:}

Maybe due to their culture, they are obviously very reticent and not open in their communications with foreigners...

\section{Informant 8:}

The average Malaysian is timid, and with this, some of them still form a perception about a person they have not even interacted with at all, and this is the problem... they did not open their minds to understand other people, yet they believe the next Nigerian is a potential criminal. 


\section{Infromant13:}

They are not like Nigerians. We usually are direct, but they are indirect and quiet...

\section{Informant 9:}

In our hostels, we live with many Malaysians, but whenever you say hello or salaam to some of them they don't respond to your greetings... and because of this I totally stopped saying hello to them.

A review of previous studies indicates that the behavioral tendencies and communicative norms such as proclivity for reticence, indirectness, and evasiveness in communication with interlocutors are among the typical communicative behaviors of people in collectivist cultures (e.g., Hofstede, 1991; Lin \& Yi, 1997; Triandis, 1995). According to Lin and Yi (1997), quietness, reservation and non-assertiveness towards foreigners are the conspicuous characteristics of the international students coming from Asia. One possible explanation for Malaysians' proclivity for silence, as claimed by the Nigerian students of the present study, could be the predominance of collectivist tendencies in the fabric of Malaysian socio-cultural context. Based on the findings of Hofstede's (1991) seminal study, there is often a correlation between the rate of power distance and collectivism. Malaysians rank first with the Power Distance Index (PDI) of 104. PDI shows people's attitudes and behaviors towards power and authority. As for indirectness, it could be hypothesized that Malaysian culture along with most of Asian cultures can be categorized under high-context cultures. The degree of context-dependency of communication is the pivotal distinguishing feature between low-and-high-context cultures. Unlike low-context cultures where direct and explicit mode of communication is utilized by the members, in high-context cultures there is a higher tendency towards using indirect and implicit style of communication in that in high-context cultures verbal communication is not deemed as the main information channel and other elements and resources existing in the context of speech are capitalized on to get the meanings across (Dodd, 1998; Hall, 1976; Samovar \& Porter, 1995).

Brislin (1993) cautions about the problematic and puzzling nature of culture-specific norms and behaviors and emphasizes the significance of giving special attention to them. Yakunina et al's ( 2012) study similarly reaffirmed the significance of attending to the specificity of intercultural communicative norms by international students, and suggested that through developing qualities such as open-mindedness, flexibility, social initiative and cultural empathy on the part of international students, they would be more likely to adjust and integrate into their host countries despite cultural and language barriers.

\section{8 (C) Author(s)}

Another theme which ran almost frequently through the comments of the informants was that of language barrier. There were a diversity of speculations about the role and function of the language barrier. For example, whereas informant 6 argued that "some Malaysians don't like speaking English because they are afraid of making mistakes", a few others linked their unwillingness to communicatively engage with Nigerians to the variant socio-contextual status of the English language in Nigeria and Malaysia. It was argued that English in Malaysia, unlike in Nigeria, is not the official language of the country; therefore, Malaysians do not have the sufficient confidence to talk to people in English. Two more comments are mentioned below:

\section{Informant 14:}

...actually majority of Malaysians don't speak English frequently, and because of that they feel shy to communicate with us because they see us as having a better command of English language... I have come across some of them that usually asked me where I learned to speak English.

\section{Informant 4:}

...sometimes their accent is difficult to understand. I sometimes can only guess what they want to say...

The participants' perception of language as a barrier to intercultural communication is in agreement with the findings of a number of other studies on international students which have found language barrier as a factor making the intercultural communication elusive (e.g., Smith \& Khawaja, 2011; Yakunina et al., 2012). There is also consistency between the findings of the present study and those of Thuraisingam and Singh's (2010) study, which found that Nigerian under-graduate students perceived the accent of Malaysians as a barrier to an effective intercultural communication. Brown (2009) argues for the role of good language skills in diminishing the distance between the host and guest communities.

The last theme recurring in the data was concerned with the perceived effect of the informants' religion (i.e., Islam vs. Christianity) on the quality of their relationship with the locals. The personal anecdotes of a Muslim and Christian participant were as follows:

\section{Informant 6 (Muslim):}

I was once arrested by a police officer because I forgot my international passport at home. He asked me where I was coming from, I told him from the University... he then asked me to identify myself with the student ID card as well as my international passport... but none was with me. He then asked me my name and I told him... and when he realized I am a 
Muslim, he said, OK I am allowing you go because you are a Muslim, but don't do this again.

\section{Informant 2 (Christian):}

As a Christian I can also say 'yes' religion is a factor... because for example majority of the law enforcement agents you see on the street are Malays... so whenever they stop you on the street, the first thing they ask is "are you a Muslim"... and even though you are not a Muslim and you tell them you are a Muslim at that point of time they can allow you go even if you have committed a crime... So there is some element of bias and double standard.

What Christian and Muslim informants of the study said about the influence of the religion evidently converged in the finding that religion functioned as a factor influencing the quality of their intercultural communication in Malaysia. While the Muslim informants believed they were treated positively particularly by the ethnic Malays, the Christian informants felt there was discrimination against them on religious grounds, and particularly practiced by the ethnic Malays. This sense of support towards Nigerian Muslims might have been inspired by factors ranging from the teachings of the Holy Book (the Quran) to the growing global trend of Islamization. The Holy Book urges the entire Muslims towards solidarity and unity and describes them regardless of their color, race and nationality, as members of a single united community: "Surely this nation of yours is one nation" (Chapter 21, verse 92). Besides this, in tandem with the growing trend of "islamization" on a global scale (Liow, 2009), Malaysia has been witnessing a resurgence of identification with Islam. A survey conducted by the Center for Public Policy Studies in 2006 (as cited in Furlow, 2009) found that being Muslim took strong precedence over being Malay or Malaysian among Malays in Malaysia. 72\% chose being Muslim as their primary identity (rather than being Malay or Malaysian). Likewise, a study on the ethno-political discourse of ordinary Malaysians found that "the Malays invoked being Muslim as the primary source of identity and imagined community, while the nonMalays cited the politicization of Islam as a cause for the increasing boundary between groups" (Buttny, Azirah \& Kaur, 2013, p. 289).

\section{CONCLUSIONS}

This article has reported findings from two focus group interviews conducted with fourteen Nigerian post-graduate students at a public university in Malaysia. The study set out to address the question of: How do Nigerian post-graduate students in a public university in Malaysia perceive their cultural, interpersonal relationships and communication challenges in the local context?
Analysis of the data revealed that almost all of the informants were cognizant of the negative change of attitudes towards Nigerians over the recent years in Malaysia. Stereotipification, religion-induced discriminations, biased coverage of Nigerians-associated events by the local media, Malaysians' natural proclivity for silence and their poor responsiveness in communicative interactions and the language barrier emerged as the main themes which rendered achieving an effective intercultural communication with the host nationals elusive and increasingly difficult.

\section{REFERENCES}

[1]. Anti-African sentiment a cause for concern. (2018, January 8). Freemalaysiatoday, From https://www.freemalaysiatoday.com/ category /nation/2018/01/08/anti-african-sentiment-a-causefor-concern-says-writer/.

[2]. Antonio, A. L. (2004). When does race matter in college friendships? Exploring men's diverse and homogeneous friendship groups. The Review of Higher Education, 27(4), 553-575.

[3]. Ar, Z. (2013, August 26). At Subang condo, ban against 'African' tenants. Malaymail Online, News Site. From http://www.themalaymailonline.com /malaysia/article/in-subang-condo-ban-againstafrican-tenants.

[4]. Barnett, G. A., \& Lee, M. (2002). Issues in Intercultural Communication. In W. B. Gudykunst \& B. Mody (Eds.), Handbook of international and intercultural communication. Thousand Oaks, CA: SAGE Publications, Incorporated.

[5]. Brislin, R. (1993). Understanding culture's influence on behavior. Harcourt Brace Jovanovich.

[6]. Brown, B. (2003). White Immigrants: A portrait of the Polish Community in London. From http://youngfoundation.org/wp- content/uploads/ 2013/ 04/White-Immigrants-A-Portrait-of-the-PolishCommunity-in-London-July-2003.pdf.

[7]. Brown, L. (2009). A Failure of Communication on the Cross-Cultural Campus. Journal of Studies in International Education, 13(4), 439-454.

[8]. Buttny, R, Azirah, H, Kaur, K (2013) Ethnopolitical discourse among ordinary Malaysians: Diverging accounts of 'the good old days' in discussing multiculturalism. Text \& Talk 33: 289-309.

[9]. Crawley, E., Swailes, S., \& Walsh, D. (2013). Introduction to International Human Resources Management. Oxford: Oxford University Press.

[10]. Dodd, C. H. (1998). Dynamics of intercultural communication (5th edn.). New York: McGraw-Hill. 
[11]. Furlow, C. A. (2009). Malaysian modernities: Cultural politics and the construction of Muslim technoscientific identities. Anthropological Quarterly, 82(1), 197-228.

[12]. Gudykunst, W. (1998). Bridging differences: effective intergroup communication. London: Sage.

[13]. Hall, E. T. (1976). Beyond culture. New York: Dubleday Dell Publishing.

[14]. Hanassab, S. (2006). Diversity, international students, and perceived discrimination: Implications for educators and counselors. Journal of Studies in International Education, 10(2), 157-172.

[15]. Hessler, J. (2006). Death of an African student in Moscow. Cahiers du monde russe, 47(1), 33-63.

[16]. Hofstede, G. (1986). Cultural differences in teaching and learning.

[17]. Hofstede, G. (1991). Cultures and organizations: software of the mind: Berkshire: McGraw-Hill.

[18]. International Journal of Intercultural Relations, 10(3), 301-320.

[19]. Irwin, H. (1996). Communicating with Asia: Understanding People with Customs. Australia: Allen \& Unwin Pty Ltd.

[20]. Jang, D., \& Kim, D.-Y. (2010). The influence of host cultures on the role of personality in the acculturation of exchange students. International Journal of Intercultural Relations, 34(4), 363-367.

[21]. Johnson, A., Why are Africans hated in this part of Malaysia? (19 March 2018). The Pulse.ng. From https://www.pulse.ng/gist/racism-why-are-africanshated-in- this-part-of-malaysia/gjkb8be.

[22]. Kumaravadivelu, B. (2008). Cultural globalization and language education: Yale University Press.

[23]. Lai, N. (2011, December 11). Be Wary of 25,000 African 'Students". Retrieved from http://www.theborneopost.com/2011/12/11/be-waryof-25000-african-students.

[24]. Lee, J. J., \& Rice, C. (2007). Welcome to America? International student perceptions of discrimination. Higher Education, 53(3), 381-409.

[25]. Lin, G., Yi, J. (1997). Asian international students' adjustment: Issues and program suggestions. College Student Journal, 31(4), 473-479

[26]. Liow, J. C. (2009). Piety and politics: Islamism in contemporary Malaysia. Oxford: Oxford University Press.

[27]. Marlina, R. (2009). "I don't talk or I decide not to talk? Is it my culture?"- International students' experiences of tutorial participation. International Journal of Educational Research, 48(4), 235-244.
[28]. Mary Alexander (2020), 'Do not rent to African' sign from Malaysia, not China. (2020, May 26). Africa Check, From https://africacheck.org/factchecks/fbchecks/do-not-rent-african-sign-malaysianot-china

[29]. Ministry of Education (2012). Statistic of Malaysia Higher Education 2011. http://www.mohe.gov.my/web_statistik/perangkaan2 011.htm

[30]. Ministry of Education (2015). Malaysia Education Blueprint 2015-25 (Higher Edcuation). Kementerian Pendidikan Malaysia. $\quad$ Retrieved from http://hes.moe.gov.my/event/

[31]. Mohanakrishnan, A. (2020). Local artist points out racism still alive in Malaysian property renting practices (16 April 2020). The Sun Daily. From https://www.thesundaily.my/style-life/goingviral/local-artist-points-out-racism-still-alive-inmalaysian-property-renting-practices-FX2264474

[32]. MOHE. (2011). Higher Education Malaysia: Internationalization Policy 2011. Putrajaya: Ministry of Higher Education Malaysia.

[33]. Ng, K. (2018, January 9). Racism in Malaysia's housing market: how landlords get away with barring African and South Asian tenants. The South Cina Morning Post. From https://www.scmp.com/ lifestyle/article/2127261/racism-malaysia-andstruggle-africans-and-south-asians-rent-kualalumpur.

[34]. Pandian, A. (2008). Multiculturalism in higher education: a case study of Middle Eastern students' perceptions and experiences in a Malaysian University. International Journal of Asia Pacific Studies, 4(1), 33-59.

[35]. Porter, R. E., Samovar, L. A. (1997). 'An introduction to intercultural communication'. In L. A. Samovar \& R.E. Porter (Eds.). Intercultural communication: A reader (8th edn.). Belmont, CA: Wadsworth.

[36]. Poyrazli, S., \& Lopez, M. D. (2007). An exploratory study of perceived discrimination and homesickness: A comparison of international students and American students. The Journal of Psychology, 141(3), 263280.

[37]. Poyrazli, S., Thukral, R. K., \& Duru, E. (2010). International students' race-ethnicity, personality and acculturative stress. Journal of Psychology and Counseling, 2(8), 25-32.

[38]. Ruble, R. A, Zhang Y. B. (2013). Stereotypes of Chinese international students held by Americans. 
International Journal of Intercultural Relations, 37, 202-211.

[39]. Sam, D. L. (2001). Satisfaction with life among international students: An exploratory study. Social indicators research, 53(3), 315-337.

[40]. Samovar, L. A., \& Porter, R. E. (1995). Communication between cultures (2nd edn.). Belmont, CA:Wadsworth.

[41]. Smith, R. A., \& Khawaja, N. G. (2011). A review of the acculturation experiences of international students. International Journal of Intercultural Relations, 35(6), 699-713.

[42]. Talmy, S. (2010). Qualitative Interviews in Applied Linguistics: From Research Instrument to Social Practice. Annual Review of Applied Linguistics, 30, 128-148.

[43]. Therin, Francois. An International Hub for Higher Education? BorneoPost online, August 28, 2012 [cited July 10 2013]. Available from http://www.theborneopost.com/2012/08/28/aninternational-hub-for-higher-education/.

[44]. Thuraisingam, T., \& Singh, P. K. H. (2010). A Hermeneutic Phenomenological Approach to Sociocultural and Academic Adjustment Experiences of International Students. The Journal of the South East Asia Research Centre for Communication and Humanities, 2, 91-113.

[45]. Triandis, H. C. (1995). Individualism and Collectivism. Boulder,CO: Westview Press.

[46]. Tubbs, S.L., \& Moss, M. (2000). Human communication (8th edn.). Boston: McGraw-Hill, cop.

[47]. Williams, C. T., \& Johnson, L. R. (2011).Why Can't We Be Friends?: Multicultural Attitudes and Friendships with International Students. International Journal of Intercultural Relations 35(1), 41-48.

[48]. Yakunina, E. S., Weigold, I. K., Weigold, A., Hercegovac, S., \& Elsayed, N. (2012). The multicultural personality: Does it predict international students' openness to diversity and adjustment? International Journal of Intercultural Relations, 36(4), 533-540.

[49]. Yusoff, Y. M., \& Chelliah, S. (2010). Adjustment in international students in Malaysian public university. International Journal of Innovation, Management and Technology, 1(3), 275-278. 


\section{Manuscript Processing Footprints}

\section{A. Journal Volume/Issue Details}

This manuscript it published in Vol. 12 No. 012022 issue of IARS' International Research Journal (I'IRJ).

This is a Peer Reviewed (Refereed) International Journal published by IARS' Press Australia (International Association of Research Scholars) The Volume/Issue is a regular issue of the journal published in February 2022 Available at: https://researth.iars.info/index.php/curie.

\section{B. Copyright, License, and Publishing Rights}

- IARS' Press Australia (International Association of Research Scholars) respects the rights of the authors of research content published with IARS' International Research Journal. The "First Publication Rights" (FPR) to the original work accepted for publication at IARS' International Research Journal is granted to the Publisher of the Journal but copyright for all work published in the journal is retained by the author(s). Works published in the Journal is distributed under a Creative Commons Attribution 4.0 International License (CC BY 4.0). (This license lets others distribute, remix, adapt, and build upon your work, even commercially, as long as they credit you for the original creation. This is the most accommodating of licenses offered. Recommended for maximum dissemination and use of licensed materials.)

- After publishing the content with IARS' International Research Journal, the author holds complete right on the content for its amendments and reuse in any form. IARS' International Research Journal confirms that author(s) holds the copyright of the content.

- $\quad$ Author(s) grant(s) permission for their work to be indexed in part/full form in commercial and non-commercial indexes. Author(s) grant(s) permission for their work to be harvested in part/full form in commercial and non-commercial archives and distributed through them. Author(s) grant(s) permission for their work to be translated in part/full form in any language and republished and redistributed. Author(s) may enter into separate, additional contractual agreements for the non-exclusive distribution of the published version of the work, with an acknowledgement of its initial publication in this Journal.

- It is the responsibility of the author(s) to secure all necessary copyright and/or permissions for the use of third-party content in their manuscript(s). Author(s) have declared the same at the time of submission of manuscript and 'may also be required' to provide written evidence of this permission anytime in case required for any purposes.

- Publications Ethics and other Terms and Conditions as mentioned on official website of IARS' International Research Journal.

\section{Last Plagiarism Report}

SCREENED BY

$\checkmark$ iThenticate

Settings: Quotes Excluded, Bibliography Excluded

Cultural, Interpersonal Relationships and Communication

Challenges as Perceived by Nigerian Post-graduate Students in a

Public Academic Institution in Malaysia

1 part $-6,009$ words

$\begin{array}{ll}\text { Seyed } & \text { Feb 27, 2022 } \\ \text { Yasin } & \text { 8:58:36 AM } \\ \text { Yazdi- } & \\ \text { Amirkhiz } & \end{array}$

Amirkhiz

Exemption / Relaxation by Editor: None

\section{Processing Track}

\begin{tabular}{|l|l|}
\hline Date of Submission & 21 October 2021 \\
\hline Date of Final Review & 03 February 2022 \\
\hline Date of Acceptance \& Schedule & 27 February 2022 \\
\hline Date of Publishing & 28 February 2022 \\
\hline
\end{tabular}

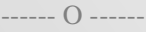

